\title{
Nanotherapeutics Shielded With a pH Responsive Polymeric Layer
}

\author{
L. KOSTKA ${ }^{1}$, V. ŠUBR ${ }^{1}$, R. LAGA ${ }^{1}$, P. CHYTIL ${ }^{1}$, K. ULBRICH ${ }^{1}$, L.W. SEYMOUR ${ }^{2}$, \\ T. ETRYCH ${ }^{1}$
}

${ }^{1}$ Department of Biomedicinal Polymers, Institute of Macromolecular Chemistry, Academy of Sciences of the Czech Republic, Prague, Czech Republic, ${ }^{2}$ Department of Clinical Pharmacology, University of Oxford, Oxford, UK

Received June 10, 2015

Accepted July 16, 2015

\section{Summary}

Efficient intravenous delivery is the greatest single hurdle, with most nanotherapeutics frequently found to be unstable in the harsh conditions of the bloodstream. In the case of nanotherapeutics for gene delivery, viral vectors are often avidly recognized by both the innate and the adaptive immune systems. So, most modern delivery systems have benefited from being coated with hydrophilic polymers. Self-assembling delivery systems can achieve both steric and lateral stabilization following surface coating, endowing them with much improved systemic circulation properties and better access to disseminated targets; similarly, gene delivery viral vectors can be 'stealthed' and their physical properties modulated by surface coating. Polymers that start degrading under acidic conditions are increasingly investigated as a pathway to trigger the release of drugs or genes once the carrier reaches a slightly acidic tumor environment or after the carrier has been taken up by cells, resulting in the localization of the polymer in acidic endosomes and lysosomes. Advances in the design of acid-degradable drug and gene delivery systems have been focused and discussed in this article with stress placed on HPMA-based copolymers. We designed a system that is able to "throw away" the polymer coat after successful transport of the vector into a target cell. Initial biological studies were performed and it was demonstrated that this principle is applicable for real adenoviral vectors. It was shown that the transfection ability of coated virus at $\mathrm{pH} 7.4$ is 75 times lower then transfection at $\mathrm{pH}$ 5.4.

\section{Key words}

Nanotherapeutics $\bullet$ Coating $\bullet \mathrm{pH}$ responsive $\bullet$ Polymers $\bullet$ HPMA

\section{Corresponding author}

L. Kostka, Department of Biomedicinal Polymers, Institute of Macromolecular Chemistry, Academy of Sciences of the Czech Republic, Heyrovsky Sq. 2, 16206 Prague 6, Czech Republic. E-mail: kostka@imc.cas.cz

\section{Introduction}

Polymers are a popular choice for the design of drug delivery carriers. The use of polymer therapeutics has evolved into a broad discipline, employing a wide range of architectures either at the macroscale (gels and hydrogels) or nanoscale (polymer-drug conjugates, polymeric micelles, nanogels and cross-linked particles, polyplexes for DNA delivery, etc.). In particular, the development of multifunctional nanoscale devices has drawn a lot of attention. In summary, the controlled release of encapsulated therapeutics is an active research field. A few strategies have been developed, including bioconjugation with cell-targeting biomolecules for specific delivery and the use of stimuli-responsive polymers to create "smart" polymer therapeutics.

Quite a lot of stimuli-responsive nanotherapeutics have been designed for gene therapy. This may be because gene therapy provides new options for treating many human diseases in situations where conventional therapeutical approaches are not available (Rolland and Felgner 1998). However, major limitations that still restrict the therapeutic use of vectors include the quick elimination of the vectors from the bloodstream due to nonspecific interaction with plasma proteins, cells of the immune system and the uptake with cells of the 
reticuloendothelial system (Lechardeur et al. 2005). Surface modifications (coating) to viral or nonviral vectors with covalently linked poly(ethylene glycols) (PEGs) and other hydrophilic polymers, which significantly prolong their circulation in plasma, ablate non-specific cell entry, evade contact with neutralizing antibodies, prevent binding to blood components and facilitate the transport of vectors to target cells, is a promising way to systemically deliver gene vectors (Dash et al. 2000, Eto et al. 2008, Fisher et al. 2001, Kreppel and Kochanek 2008, Oupický et al. 2002a, 2002b). Hydrophilic multivalent and semitelechelic $N$-(2hydroxypropyl) methacrylamide copolymers (PHPMA) with 4-nitrophenoxy (ONp) and acyl thiazolidine-2thione (TT) reactive groups enabling surface coating of both viral and nonviral gene delivery vectors have been developed and tested (Dash et al. 2000, Fisher et al. 2007, Fisher and Seymour 2010, Newman et al. 2009, Oupický et al. 2000, Sims et al. 2009, Šubr et al. 2006).

The multivalent reactive copolymer of HPMA and $N$-methacryloylglycylglycine 4-nitrophenyl ester was reacted with cationic liposome-DNA complexes (lipoplexes) to form an external polymer coat. Polymer coating increased the lipoplex diameter that was proportional to the amount of polymer used and saw a reduction in surface charge from strongly positive to neutral. Polymer-coated lipoplexes exhibited increased stability to protein binding compared to untreated liposomes and reduced non-specific uptake into in vitro cells (Papanicolaou et al. 2004).

Hydrophilic multivalent PHPMA copolymers with maleimide and pyridyl disulfide reactive groups were used to effect surface modification of adenovirus with a genetically introduced cysteine residue in the hyper-variable-region 5 of the hexon. A cysteine thiol group allows both irreversible attachment of shielding moieties via thioether bonds and reversible attachment via disulfide bonds (Prill et al. 2014).

Although covalently bound hydrophilic polymers sufficiently protect the vectors against undesirable interactions with blood-plasma components and efficiently mediate cellular uptake, the inability of these systems to throw away the shielding polymer layer after cell internalization results in a dramatic decrease in their transfection efficiency (Walker et al. 2005).

Therefore, new types of polymers for coating of gene delivery vectors have been developed. These polymers enable the stable coating of vectors during circulation in the blood stream, sufficient protection against interactions with blood-plasma components and after cell internalization of polymer coated vectors, they enable the throwing away of the shielding polymer layer, thus restoring transfection efficiency (see Scheme 1).

The strategy of removing the shielding polymer layer from the surface of gene vectors is based on the hydrolysis of acid-labile bonds in endosomes (Meyer and Wagner 2006) or induced by an intracellular reductive environment (Oupicky and Diwadkar 2003, Oupicky et al. 2002a, 2002b, Saito et al. 2003).

Among the various existing stimuli-responsive systems, $\mathrm{pH}$-sensitive polymers have been widely studied for drug and gene delivery applications. Indeed, it has been shown that the environment in tumor tissue is often 0.5-1.0 pH units lower than in normal tissue (Tannock and Rotin 1989). Moreover, a larger $\mathrm{pH}$ shift from 7.2-7.4 in the blood or extracellular spaces to 4.0-6.5 in the various intracellular compartments takes place during cellular uptake, and this can be used for intracellular drug or gene delivery.

Pegylation reagents containing acetal or ketal pH-sensitive shielding of DNA polyplexes were described by Knorr et al. (2007, 2008a, 2008b).

The bifunctional, endosomal $\mathrm{pH}$-cleavable reagent OPSS-PEG-HZN-Chol [ $\omega$-2-pyridyldithio poly (ethylene) glycol $\alpha$-(butyraldehyde) ( $N_{1}$-cholesteryloxycarbonyl-1,2-diaminoethaneamidocarboxy) pyridyl hydrazone] as a bioreversible surface shielding DNA lipopolyplexes was described by Nie et al. (2011).

Hydrophilic multivalent and semitelechelic PHPMA with TT reactive groups in their side chains or end of polymer chain bound to the polymeric backbone via disulfide spacers were used for studying the coatingdecoating of amino-group modified polystyrene (PS) latex beads, PLL/DNA complexes (Carlisle et al. 2004, Laga et al. 2009), cowpea mosaic viruses (Laga et al. 2010), siRNA (Kostka et al. 2011) and adenoviruses (Carlisle et al. 2008). It was shown that incorporating a low content of quaternary ammonium groups into the TT reactive HPMA copolymers improved the coating efficiency of zwitterionic vesicles (Koňák et al. 2008) and adenoviruses (Carlisle et al. 2008, 2009, Šubr et al. 2009).

\section{Methods}

\section{Chemicals}

Methacryloyl chloride, 1-aminopropan-2-ol, 4,5-dihydrothiazole-2-thiol, 2-aminoethyl-trimethyl- 
ammonium chloride hydrochloride, 4-oxopentanoic acid (OPA), 6-oxoheptanoic acid(OHA), 6-hydrazinonicotinic acid (HNA), $N$-(3-dimethylaminopropyl)- $N$ 'ethylcarbo-diimide hydrochloride (DMAEC.HCl), $N, N^{\prime}$ dicyclo-hexyl-arbodiimide (DCC), 4-(dimethylamino) pyridine (DMAP), triethylamine $\left(\mathrm{Et}_{3} \mathrm{~N}\right)$, trifluoracetic acid (TFA), 2,2'-azobis(isobutyronitrile) (AIBN), dichloromethane (DCM), tetrahydrofurane (THF), $N, N$ dimethylformamide (DMF), dimethyl sulfoxide (DMSO)and calcium hydride were from Sigma-Aldrich. 6-( $N$ '-tert-butyloxycarbonyl-hydrazino)-nicotinic acid (Boc-HNA) was purchased from Merck. N-(3Aminopropyl)methacrylamide hydrochloride was from Polysciences, Inc. All other chemicals and solvents were of analytical grade.

\section{Monomer synthesis}

$\mathrm{N}$-(2-hydroxypropyl)methacrylamide (HPMA) was synthesized by modified reaction of methacryloyl chloride with 1-aminopropan-2-ol in dichloromethane in the presence of sodium carbonate as described by Ulbrich et al. (2000).

6-Methacrylamidohexanohydrazide (Ma-ah$\mathrm{NHNH}_{2}$ ) was prepared by a two-step procedure. Methyl 6-aminohexanoate hydrochloride was reacted with methacryloyl chloride in dichloromethane in the presence of sodium carbonate to form methyl-6-methacrylamidohexanoate. The Ma-ah- $\mathrm{NHNH}_{2}$ was obtained by hydrazinolysis of methyl-6-methacrylamidohexanoate with hydrazine hydrate in methanol as described by Etrych et al. (2008).

2-Methyl- $N$ - $\{5$-[1-methyl-6-oxo-6-(2-thioxothiazolidin-3-yl)-hexylidene-hydrazinocarbonyl]-pentyl\}acrylamide (Ma-ah-NHN=OHA-TT) (see Scheme 2) was prepared by a two-step procedure as described in follows: Ma-ah-NHNH $\mathrm{N}_{2}(0.15 \mathrm{~g}, 0.703 \mathrm{mmol})$ was dissolved in methanol dried with $\mathrm{CaH}_{2}(1 \mathrm{ml})$ and 6-oxoheptanoic acid (OheA) dried over $\mathrm{P}_{2} \mathrm{O}_{5}$ was added $(0.113 \mathrm{~g}$, $0.780 \mathrm{mmol})$ in the presence of 4-(1,1,3,3tetramethylbutyl) pyrocatechol as inhibitor. Reaction was catalyzed by addition of acetic acid ( $5 \mathrm{ul}$ ) and carried out for $2 \mathrm{~h}$ at room temperature. The methanol was evaporated and the oily residue was dried for $1 \mathrm{~h}$ on vacuum. The oily residue was dissolved in dichloromethane $(2 \mathrm{ml})$, 4,5-dihydrothiazole-2-thiol $(0.093 \mathrm{~g}, 0.780 \mathrm{mmol})$ was added followed by addition of $N$-(3-dimethylaminopropyl)- $N$ '-ethylcarbodiimide hydrochloride (DMAEC $\cdot \mathrm{HCl})(0.180 \mathrm{~g}, 0.94 \mathrm{mmol})$ and catalytic amount of DMAP. Reaction mixture was stirred for $3 \mathrm{~h}$ at room temperature. Reaction mixture was diluted with dichloromethane $(10 \mathrm{ml})$ and extracted 3 times with $\mathrm{NaHCO}_{3}$ solution (2 wt\%, $\left.10 \mathrm{ml}\right)$. The organic layer was separated and dried with a $\mathrm{Na}_{2} \mathrm{SO}_{4}$. The dichloromethane was evaporated in vacuum the oily residue was dissolved in dried methanol $(2 \mathrm{ml})$ and purified on Sephadex LH-20 column in methanol. The methanol was evaporated and oily product was dried on vacuum and stored in refrigerator. Yield $0.085 \mathrm{~g}$ (29\%). Elemental analysis: calc./found $\mathrm{C}=54.52 / 54.33 \%$; $\mathrm{H}=7.32 / 7.21 \%$; $\mathrm{N}=12.72 / 12.46 \%$; $\mathrm{S}=14.55 / 13.84 \%$.

1-(2-thioxo-thiazolidin-3-yl)-pentane-1,4-dione (OPA-TT) was prepared by reaction of 4-oxopentanoic acid (OPA) with 4,5-dihydrothiazole-2-thiol in the presence of $N, N^{\prime}$-dicyclohexylcarbodiimide (DCC). 4-Oxopentanoic acid $(2.85 \mathrm{~g}, 24.5 \mathrm{mmol})$ and 4,5-dihydrothiazole-2-thiol (2.93 g, $24.5 \mathrm{mmol})$ were dissolved in THF $(20 \mathrm{ml})$ and cooled to $-10^{\circ} \mathrm{C}$. $N, N^{\prime}$-dicyclohexylcarbodiimide (DCC) $(5.57 \mathrm{~g}, 27 \mathrm{mmol})$ was dissolved in THF $(50 \mathrm{ml})$ and cooled to $-10^{\circ} \mathrm{C}$. Cooled solutions were mixed together, catalytic amount of DMAP was added and reaction mixture was kept at $-10{ }^{\circ} \mathrm{C}$ for $2 \mathrm{~h}$ and then at $5^{\circ} \mathrm{C}$ for $16 \mathrm{~h}$. Precipitated dicyclohexylurea was filtered off, THF was evaporated and product was crystallized from ethyl acetate. Yield: 3.5 g (72.0 \%). M.p. $82{ }^{\circ} \mathrm{C}$. Elemental analysis: calc./found $\quad \mathrm{C}=44.22 / 44.34 \% ; \quad \mathrm{H}=5.1 / 5.23 \%$; $\mathrm{N}=6.45 / 6.47 \%$; $\mathrm{S}=29.51 / 28.87 \%$.

(6-hydrazino-pyridin-3-yl)-(2-thioxo-thiazolidin3-yl)methanone hydrochloride (HNA-TT.HCl) was prepared in two steps according to following procedure: To a mixture of Boc-HNA (100.0 mg, $0.40 \mathrm{mmol}$ ) and TT $(51.8 \mathrm{mg}, 0.43 \mathrm{mmol})$ in ethyl acetate $(15 \mathrm{ml})$ cooled on $4{ }^{\circ} \mathrm{C}$ was added DCC (51.8 $\left.\mathrm{mg}, 0.43 \mathrm{mmol}\right)$ dissolved in $5 \mathrm{ml}$ ethyl acetate. The reaction was catalyzed by addition of a few crystals of DMAP and resulting mixture was kept at $-18^{\circ} \mathrm{C}$ for $2 \mathrm{~h}$ and then at $4{ }^{\circ} \mathrm{C}$ overnight. Afterwards, $0.1 \mathrm{ml}$ of acetic acid was added and reaction mixture was stirred for $1 \mathrm{~h}$ at room temperature. The formed dicyclo-hexylurea was filtered off and the crude compound was purified by silica gel column chromatography using a gradient of EtOAc/hexan mixture as the eluent. The solvent was evaporated in vacuum, obtained residue was dissolved in $10 \mathrm{ml} 4 \mathrm{M}$ $\mathrm{HCl} /$ dioxan and stirred $3 \mathrm{~h}$ at room temperature. The resulting product was isolated by precipitation into $\mathrm{Et}_{2} \mathrm{O}$. Yield was $100.8 \mathrm{mg}$. Elemental analysis: calc./found $\mathrm{C}=37.17 / 36.28 \% ; \quad \mathrm{H}=3.81 / 3.42 \% ; \quad \mathrm{N}=19.27 / 19.11 \%$; $\mathrm{S}=22.05 / 21.86 \%$. ${ }^{1} \mathrm{H}-\mathrm{NMR}$ (DMSO): $\delta=3.27$ (t, H2), 
4.64 (t, H2), 7.20 (d, H1); 8.37 (d, H1); 8,92 (s, H1).

\section{Polymer synthesis}

The multivalent reactive copolymer poly(HPMA-co-Ma-Ah-NHN=OHA-TT) Cop 1 (see Scheme 3$)$ was prepared by solution radical copolymerization of the HPMA $(0.25 \mathrm{~g}, 1.75 \mathrm{mmol})$ and Ma-Ah-NHN=OHA-TT $(0.085 \mathrm{~g}, 0.19 \mathrm{mmol})$ in DMSO $(1.87 \mathrm{ml})$ initiated with AIBN $(0.034 \mathrm{~g})$ at $60{ }^{\circ} \mathrm{C}$ for $6 \mathrm{~h}$ (Šubr and Ulbrich 2006). Polymer was isolated by precipitation into mixture acetone diethylether (2:1), filtered off washed with acetone, diethylether and dried in vacuum. Yield 0.265 g. Content of TT groups 7.75 mol \%, Mw 45000 and Mw/Mn 2.36.

Synthesis of reactive multivalent terpolymer poly[(HPMA)-co-(AEMA-OPA-HNA-TT)-co(TMAEM)] Cop 5 (see Scheme 4) started from polymeric precursor poly[(HPMA)-co-(AEMA-BOC)-co-(TMAEM)], which was prepared by radical solution polymerization of HPMA (1.0 g, $6.98 \mathrm{mmol})$, BOC-AEMA (0.171 g, 0.79 mmol) and TMAEM (0.025 g, $0.12 \mathrm{mmol})$ in DMSO $(5.83 \mathrm{ml})$ using $\operatorname{ABIN}(0.159 \mathrm{~g}, 0.97 \mathrm{mmol})$ as initiator. The polymerization was carried out at $60^{\circ} \mathrm{C}$ for $16 \mathrm{~h}$ in a glass pressure tube under argon atmosphere. The polymer was isolated by precipitation into 20 -fold excess of a diethyl ether/acetone (1:3) mixture, filtered off, dissolved in methanol and purified by Sephadex ${ }^{\mathrm{TM}}$ LH-20 size-exclusion chromatography in methanol. The purified polymer was precipitated with 20 -fold excess of a diethyl ether, filtered off and incubated in the TFA : TIPS : $\mathrm{H}_{2} \mathrm{O}$ (95:2.5:2.5) mixture $(10 \mathrm{ml})$ for $2 \mathrm{~h}$. The starting precursor was obtained by precipitation of reaction mixture into 20-fold excess of diethyl ether. Yield $1.054 \mathrm{~g}(88.1 \%)$.

A mixture of $0.3 \mathrm{~g}$ poly[(HPMA)-co-(AEMA)co-(TMAEM)] $\left(0.19 \mathrm{mmol} \sim \mathrm{NH}_{3}^{+}\right.$groups $)$and $54.0 \mu \mathrm{l}$ EDIPA (0.39 mmol) was dissolved in $2.0 \mathrm{ml}$ DMSO and added drop-wise to a stirred solution of $50.7 \mathrm{mg}$ OPA-TT $(0.23 \mathrm{mmol})$ in $2.0 \mathrm{ml}$ DMSO. After $12 \mathrm{~min}$ the reaction was stopped and the modified polymer was isolated by precipitation into a 40-fold excess of diethyl ether/acetone (1:1) mixture. The crude polymer was filtered off, dissolved in methanol and chromatographically purified on Sephadex ${ }^{\mathrm{TM}}$ LH-20 in methanol. The purified polymer was isolated by precipitation into a 40 -fold excess of diethyl ether. The yield was $0.232 \mathrm{~g}(77.3 \%)$.

To a solution of $0.15 \mathrm{~g}$ poly[(HPMA)-co(AEMA-OPA)-co-(TMAEM) $] \quad(0.1 \mathrm{mmol} \sim(\mathrm{C}=\mathrm{O})$ groups) in $3.0 \mathrm{ml}$ dimethylacetamid was drop-wise added HNA-TT.HCl dissolved in $1.0 \mathrm{ml}$ dimethylacetamid. The reaction was catalyzed by addition of $1.0 \mu$ concentrated $\mathrm{H}_{2} \mathrm{SO}_{4}$ and the mixture was stirred $24 \mathrm{~h}$ at room temperature. The resulting polymer was obtained by precipitation of the reaction mixture into a 40 -fold excess of diethyl ether/acetone (1:3), filtered off, dissolved in methanol and chromatographically purified on Sephadex $^{\mathrm{TM}}$ LH-20 in methanol. The purified polymer was isolated by precipitation into a 40 -fold excess of diethyl ether. The yield was $0.139 \mathrm{~g}(92.7 \%)$. Content of TT groups $6.0 \mathrm{~mol} \%$, content of QA groups $1.2 \mathrm{~mol}$ \%, Mw 44 000, Mw/Mn 2.17.

The content of TT reactive groups in HPMA copolymers was determined spectrophotometrically in methanol $\left(\varepsilon_{305}=108001 \mathrm{~mol}^{-1} \mathrm{~cm}^{-1}\right)$. The weight-average molecular weight $M_{w}$ and polydispersity $M_{w} / M_{n}$ of copolymers were determined by SEC on HPLC Shimadzu with Superose $6^{\mathrm{TM}}$ column equipped with UV, differential refractometer Optilab ${ }^{\circledR}$ rEX and multiangle light scattering detector DAWN ${ }^{\circledR} 8^{\mathrm{TM}}$ (Wyatt Technology Corp., USA). 0.3 M sodium acetate buffer ( $\mathrm{pH}$ 6.5) containing $0.5 \mathrm{~g} / 1$ sodium azide was used as the mobile phase. The flow rate was $0.5 \mathrm{ml} / \mathrm{min}$.

\section{Coating of latex particles}

$0.5 \mathrm{ml}(0.301 \mathrm{mg} / \mathrm{ml})$ of the latex bead suspension and $20 \mathrm{ml}$ of polymer solution containing the required amount of a coating polymer (freshly prepared in $10 \times 10^{-3} \mathrm{M}$ HEPES, $\mathrm{pH}=7.4$ ) were mixed and then $20 \mathrm{ml}$ of $1 \mathrm{M}$ HEPES, $\mathrm{pH}=8.7$ was added in order to adjust the $\mathrm{pH}$ to 8.2 . The final concentrations of coating polymers in solution ranged from 0.062 to $4 \mathrm{mg} / \mathrm{ml}$. The solution was stirred thoroughly, incubated for $30 \mathrm{~min}$, diluted 1000 times with HEPES, $\mathrm{pH}=8.2$, and finally $0.2 \mathrm{ml}$ of the solution was transferred onto the chamber slide (Lab-Tek, Nunc, USA). Samples were measured immediately (within $1 \mathrm{~h}$ after the coating started). The solutions for DLS were prepared in the same way but in higher amounts (2 $\mathrm{ml}$ of latex suspension) and used without any dilution.

\section{Dynamic and static light scattering measurements}

Static light scattering (SLS) measurements were carried out with a homemade instrument equipped with a $30-\mathrm{mW}$ He-Ne laser in the angular range $30-140^{\circ}$. The obtained data were analyzed using the Zimm plot procedure. Calculation of the amount of bound coating copolymer on the particle surface was made by the 
procedure used in the previous paper. The accuracy of the Mw measurements was about $1 \%$. The refractive index increments of polystyrene latex particles $(0.257 \mathrm{ml} / \mathrm{g})$ and coating copolymers $(0.167 \mathrm{ml} / \mathrm{g})$ were taken from literature (Laga et al. 2007).

Polarized dynamic light scattering measurements were performed within the same instrument as mentioned above (SLS) with an ALV 5000 multibit autocorrelator. Data were analyzed using the GENDIST program. The experimental error of Rh-determination was typically about $3 \%$. Kinetics of coating processes was monitored through changes of the particle hydrodynamic radius $(\mathrm{Rh})$ and scattering intensity (Is) at the scattering angle $173^{\circ}$ on a Nano-ZS, Model ZEN3600 (Malvern Instruments, UK) zetasizer.

\section{In vitro experiments - monolayer infection}

Studies were performed as described previously by Fisher et al. (2001). PC3 cells (96well plate,104/well, $24 \mathrm{~h}$ ) were infected with Ad5 or polymer coated Ad5 (500 copies/cell). After $90 \mathrm{~min}$ infection media were removed and washing in $150 \mu \mathrm{l}$ PBS performed and fresh media added. $24 \mathrm{~h}$ later media were removed, washing $(150 \mu \mathrm{l}$ PBS) performed and luciferase measured (reporter system E151A (Promega) and a luminometer (LB9507, Berthold)).

Table 1. Characteristics of prepared PHPMA.

\begin{tabular}{lccccc}
\hline & Mw & Mw/Mn & T & QA & Linker \\
\hline Cop 1 & 37500 & 1.9 & 5.5 & 0 & OHA $^{\mathrm{a}}$ \\
Cop 2 & 39300 & 1.7 & 5.8 & 2.0 & OHA $^{\text {Op } 3}$ \\
Cop 4 & 45300 & 2.3 & 7.5 & 0 & OHA \\
Cop 5 & 45300 & 2.3 & 4.8 & 3.0 & OHA $^{\text {. }}$ \\
\hline
\end{tabular}

${ }^{\text {a }}$ 5-oxo-hexanoic acid, ${ }^{b}$ hydrazino-nicotinic acid.
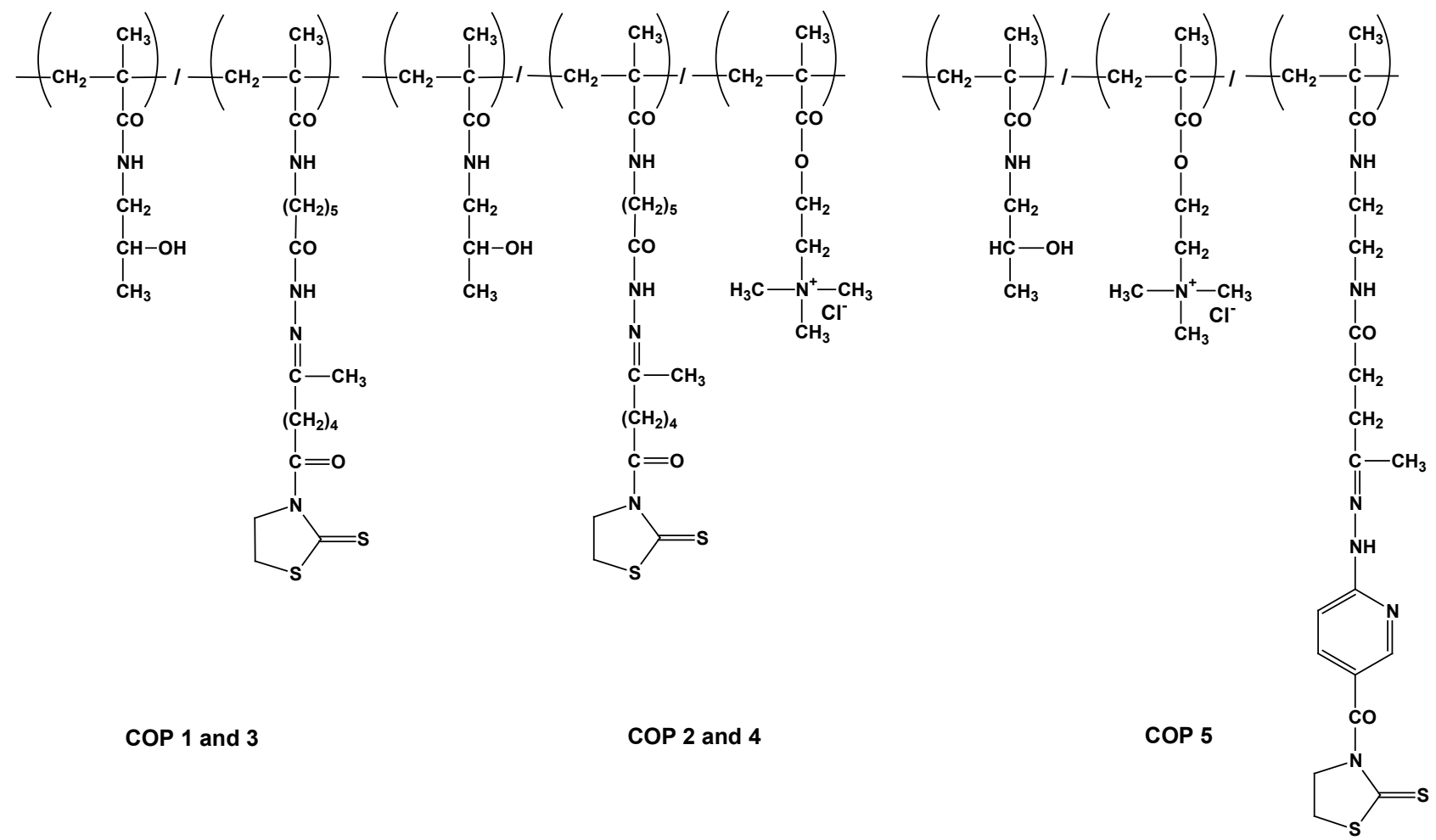

Fig. 1. Structures of synthetized HPMA-based copolymers. 


\section{Results and Discussion}

In this paper, we describe the synthesis and physico-chemical characterization of HPMA-based copolymers containing reactive TT groups designed for surface modification of gene-delivery vectors. Multivalent PHPMA with TT groups randomly distributed along the polymer chain are employed and the TT groups are at the same time attached to the polymer backbone via spacers containing biodegradable $\mathrm{pH}$ sensitive hydrazone bonds. We describe a detailed study of reactions enabling an efficient coating-decoating of gene delivery systems and a model system comprised of amino group-modified polystyrene latexes.

We synthesized appropriate monomers and novel PHPMA and we determined the potential of the copolymers in the synthesis of stimuli responsible nanotherapeutics. These new reactive copolymers were prepared by solution radical copolymerization of the respective TT-monomer with HPMA in DMSO using AIBN as an initiator. The physico-chemical characteristics of the polymers as molar mass, contents of reactive and quarterly ammonium (QA) groups are summarized in Table 1. The structures of the copolymers are depicted in Figure 1.

In principle, semitelechelic polymers allow for a well-defined coating of nanotherapeutics, especially polyelectrolyte complexes, as well as control of the quality of surface modification by varying the number of attached polymer chains and their length. However, multivalent copolymers enable a more efficient coating and better lateral stabilization of vectors by cross-linking the surface, although the structure of the surface layer is less defined. Here we would like to show how our polymers can modify the surface of Adenovirus 5 (Ad5).

Ad5 is one of the most commonly-used gene delivery vectors due to its highly efficient and regulated pathway of infection (Greber et al. 1993). However, its clinical application has been limited by the failure to gain full control of its tropism or ameliorate the strong innate and adaptive immune responses generated against it. One approach to taming Ad5 and improving its biocompatibility has been focused on making genetic modifications to its capsid proteins or to exchange them entirely for those of serotypes not normally associated with human infection (Roberts et al. 2006, Wickham et al. 1997). However, the cellular tropism of Ad5 is determined by a range of capsid proteins - cell receptor interactions, with an infection pathway that involves the knob and shaft domains of the fiber (Bergelson et al. 1997). Similarly, the pre-existing immunity against Ad5 is both commonplace and targeted to a wide range of capsid epitopes (Sumida et al. 2005). Furthermore, fixation by complement and instigation of innate immunity may be achieved even in the absence of specific anti-adenovirus antibodies (Cichon et al. 2001). This raises the possibility that capsid proteins from 'rare' serotypes will still be inactivated by complement and IgM binding despite a lack of pre-exposure. Furthermore, it is the capsid as a whole that, following intravenous delivery, drives the strong interaction with the reticuloendothelial system (RES) and the resulting pro-inflammatory cytokine cascade, even in previously native mice and non-human primates (Muruve et al. 2004). Therefore, the use of genetic engineering to modify $\mathrm{Ad} 5$ and to create a platform delivery vector that is devoid of all mechanisms of natural infection, hidden from innate and pre-existing immune responses and does not trigger anti-capsid mediated adaptive immunity represents a substantial challenge. The complexity and magnitude of the genetic engineering necessary to meet these requirements necessitates the use of special producer cell lines and often leads to inefficiencies in production and the ultimate loss of infective capacity.

Chemical modification using reactive polymers to 'stealth' Ad5 offers a comparatively simple, efficient and non-heritable alternative to genetic modification that can be performed on virus post-production and purification.

The concept was first described by O'Riordan et al. (1999), who utilized a PEG bearing a single amine reactive group to demonstrate protection against neutralization and the maintenance of infection activity. Shortly after, Fisher et al. (2001) used a multivalent reactive polymer based on HPMA to enable the coating and retargeting of Ad5. This $16.5 \mathrm{kDa}$ polymer presented multiple amine reactive $\mathrm{ONp}$ groups along its main chain, which was supposed to react with the capsid in a cooperative manner, enhancing coating without crosslinking neighboring Ad5 particles. It was found through ${ }^{14} \mathrm{C}$-trace labelling that more than 900 polymers coated each virus and that each polymer was attached at 14 points. It is notable that despite no attempt being made to achieve site specific capsid modification and little regard being paid to the influence of polymers on the intracellular translocation pathway of $\mathrm{Ad}$, infective capacity was retained or redeemable in these studies. Before using of our new copolymer for Ad5 coating, we 


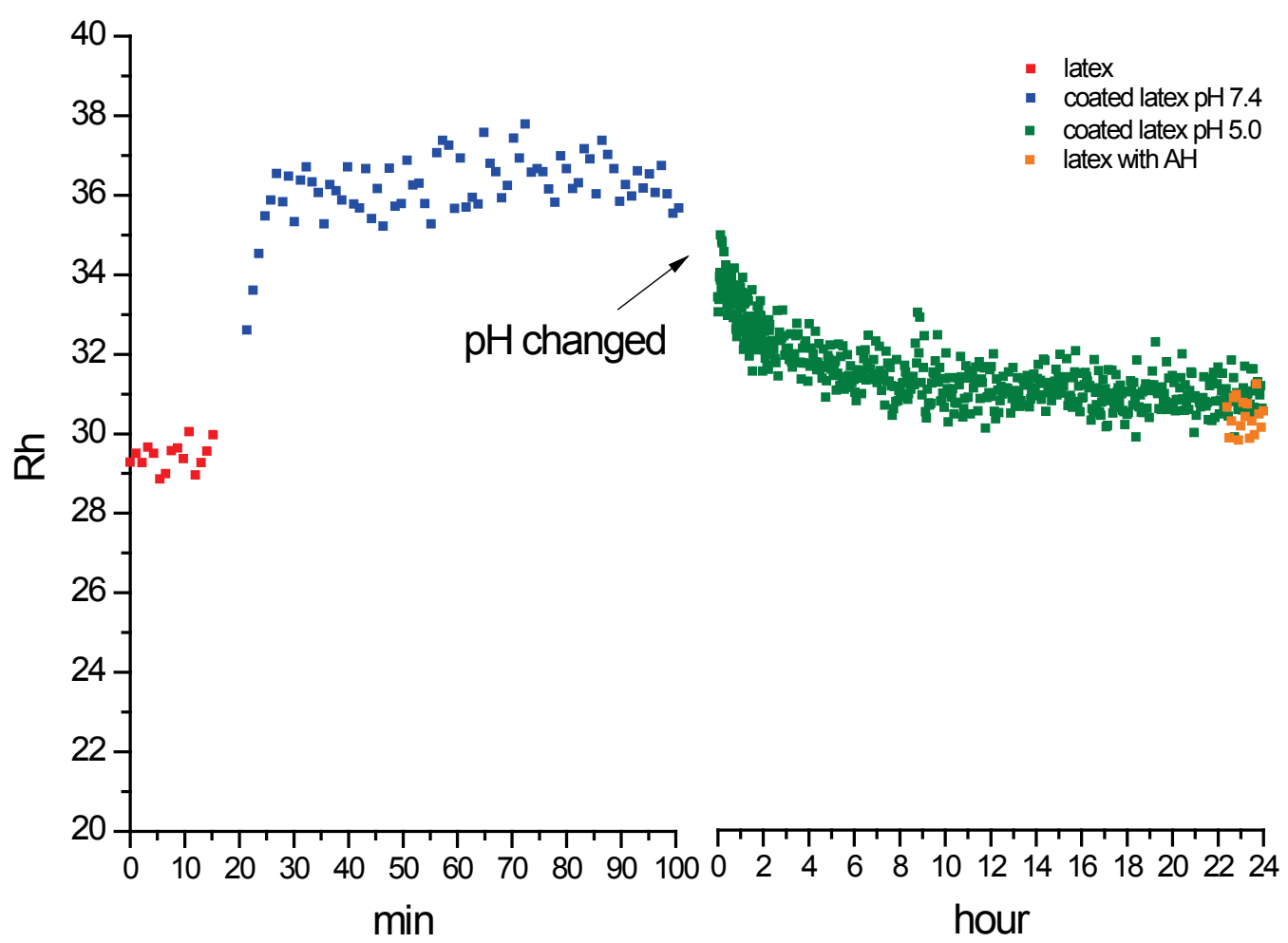

Fig. 2. The addition of Cop 1 to amino latex particles results in the surface modification of these particles, which is demonstrated by an increased hydrodynamic radius. Changes to $\mathrm{pH}$ evoke removal of the polymer coat from the latex particles, which results in the value of the hydrodynamic radius returning to the value of an unmodified latex. The reaction was performed in $10 \mathrm{mM} \mathrm{HEPES} \mathrm{pH} \mathrm{7.4.} \mathrm{Data} \mathrm{were}$ obtained from DLS.

decided to prove the concept of a pH-responsive shielding layer on amino modified latex nanoparticles. Coating model latex particles bearing amino groups on their surface using a covalent coupling with acylating TT reactive groups incorporated in highly hydrophilic multivalent PHPMA structures were successfully demonstrated by changes in nanoparticle size (Fig. 2). Within 10 min after mixing latex beads with the shielding polymer, the hydrodynamic radius increased from 29 to $37 \mathrm{~nm}$, which exactly corresponded to the size of the shielding polymer $(\mathrm{Rh} \sim 4 \mathrm{~nm})$. The change in $\mathrm{pH}$ from 7.4 to 5.0 caused the polymer coat to be removed from the latex particles, which resulted in the value of the hydrodynamic radius to return to the value of unmodified latex.

Šubr et al. (2009) published findings that the inclusion of side chains bearing a small amount of positively charged QA groups improves the electrostatic interaction between the polymers with negatively charged Ad5 hexon proteins. Based on these findings, we decided to also incorporate QA groups in our copolymers (see characteristics in Table 1 and structures of synthetized copolymers in Figure 1). An adenovirus encoding luciferase reporter gene was coated with a range of concentrations of cop 3 or 4 and then incubated at $\mathrm{pH} 7.4$ or 5.0 before being added to prostate cancer PC3 cells. The level of transfected luciferase was quantified $24 \mathrm{~h}$ later. We found increasing shielding ability of polymers as concentrations increased (Fig. 3). When the same doses of shielding copolymers are compared, one can see the contribution of QA groups to the coating efficacy (decreased transfection). At $2 \mathrm{mg} / \mathrm{ml}$, the difference is clearly visible. Unfortunately, the presence of QA groups slows down the efficacy of the deshielding procedure. The time dependence can clearly be seen in Figure 4. We used the highest amount of shielding polymers (20 $\mathrm{mg} / \mathrm{ml}$ ) from the previous study. So the transfection ability of Ad5 at $\mathrm{pH} 7.4$ was decreased 2.5 times. Transfection activity increase of 1.5 times was achieved after $24 \mathrm{~h}$ of incubation at $\mathrm{pH}$ 5.0. But at this concentration of shielding polymers, we never saw the full restoration of transfection activity compared to an unmodified virus.

The fact that the restoration of transfection activity of shielded Ad depended on many factors is also demonstrated in Figure 5. There you can see that 2 or $5 \mathrm{~h}$ of pre-incubation of shielded Ad at varying $\mathrm{pH}$ increase the efficacy of transfection. If $\mathrm{pH}$ is changed from 7.4 to 


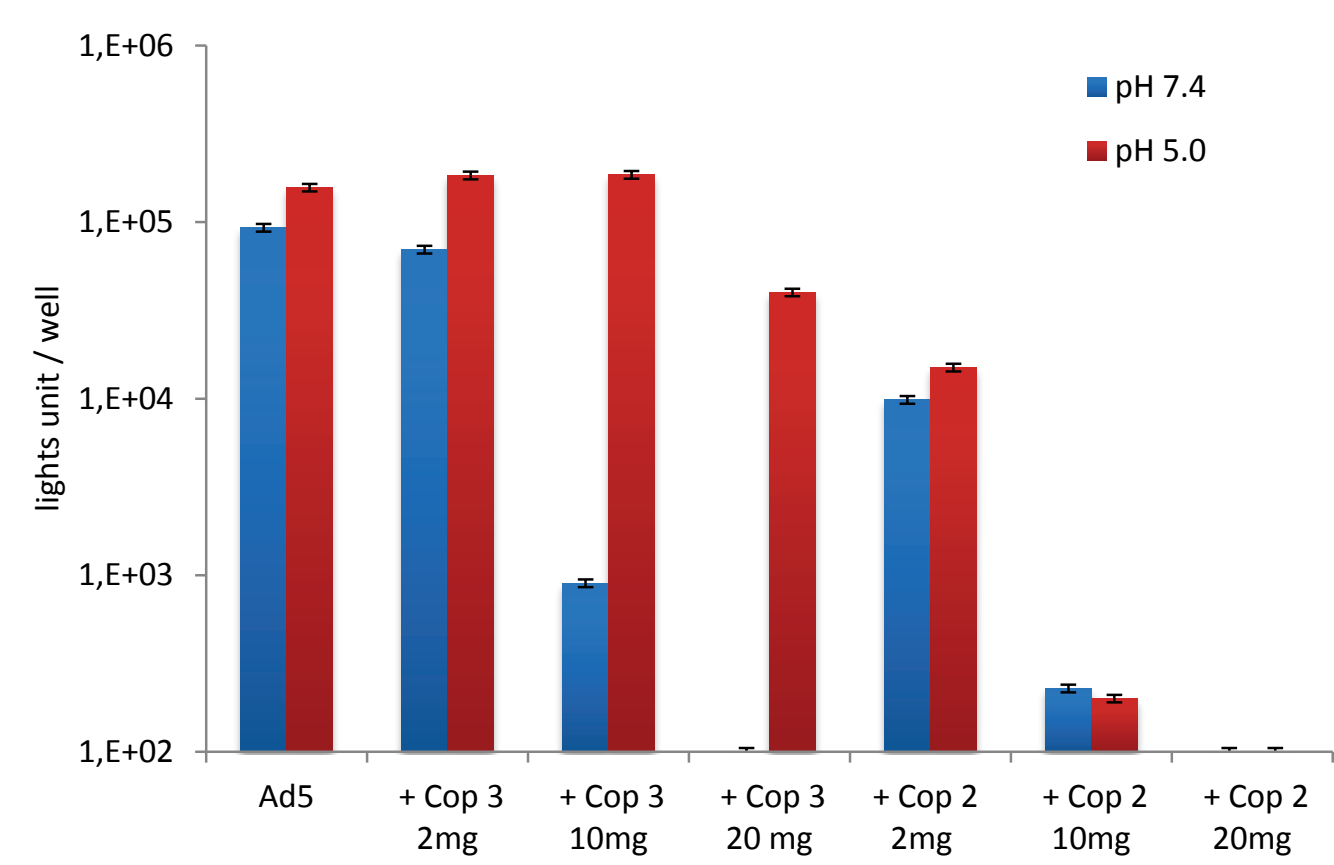

Fig. 3. An adenovirus encoding luciferase reporter gene was coated with a range of concentrations ( 10 or $20 \mathrm{mg} / \mathrm{ml}$ ) of cop 2 or 3 and then incubated in PBS at pH 7.4 or 5.0 before being added to prostate cancer PC3 cells. Luciferase was quantified 24 hours later. $N=3$.

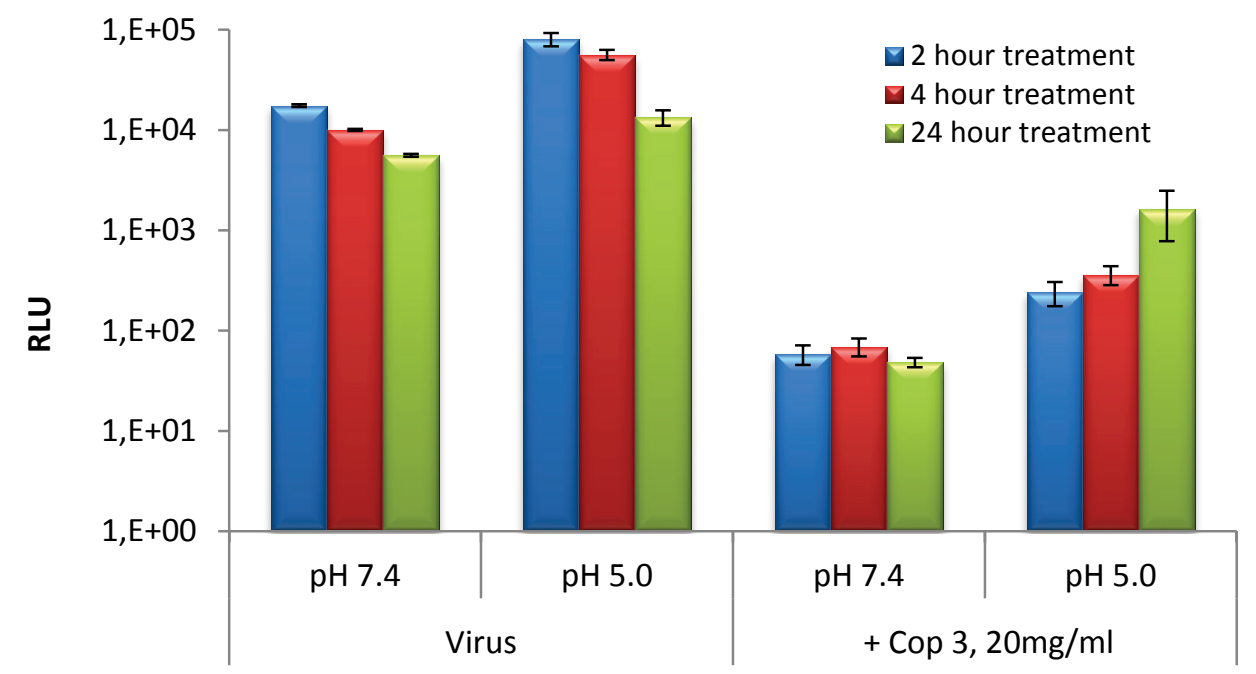

Fig. 4. An adenovirus encoding luciferase reporter gene was coated with copolymer $3(20 \mathrm{mg} / \mathrm{ml})$ and then incubated at in PBS at pH 7.4 or 5.0 before being added to prostate cancer PC3 cells for different time periods. Luciferase was quantified 24 hours later. N=3, SD shown.

5.4, the transfection efficacy is 2.5 orders of magnitude higher in the case of $2 \mathrm{~h}$ of pre-incubation and 2 orders of magnitude higher in the case of $5 \mathrm{~h}$ of preincubation. In this figure, you can see the varying stability of hydrazone bonds at different $\mathrm{pH}$ levels. The hydrazone bond shows the greatest amount of stability at $\mathrm{pH} 7.4$ and is rapidly cleaved at $\mathrm{pH}$ 4.4. Hydrazino-nicotinic acid as a linker between the reactive group and the polymer backbone was used in this experiment.

\section{Conclusions}

We designed a system that is potentially able to "throw away" the polymer coat after successful transport of the vector into a target cell. Proof of this principle was shown in studies with model latex particles and confirmed with adenoviruses in vitro studies. The efficiency of coating nanoparticles with a reactive HPMA copolymer at $\mathrm{pH} 7.4$ and decoating at $\mathrm{pH} 5.0$ was determined by changes in the hydrodynamic radius $\left(R_{\mathrm{h}}\right)$ of uncoated and PHPMA-coated model nanoparticles by 


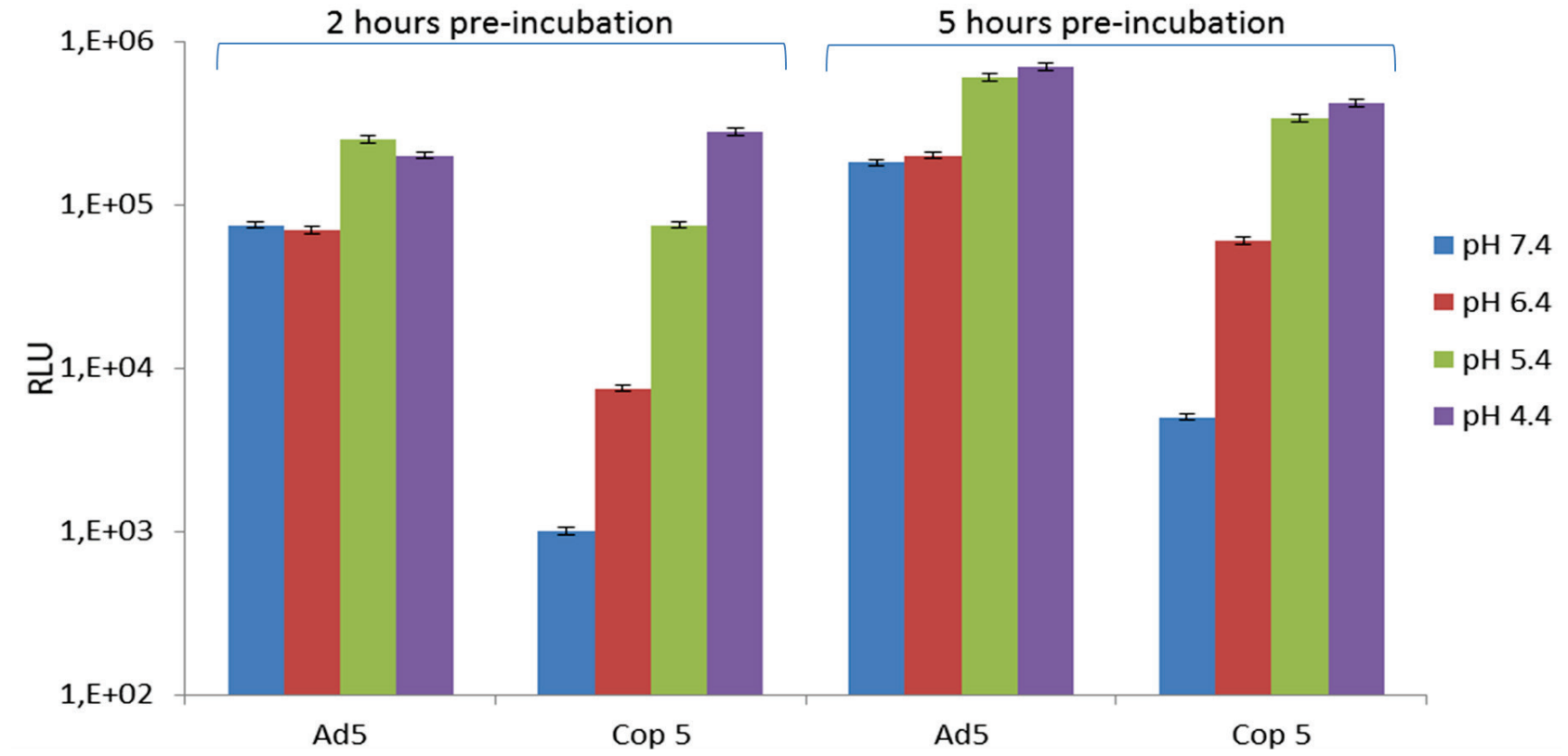

Fig. 5. Coating of $\mathrm{Ad}$ with Cop 5 in a scale of $\mathrm{pH}$, after 2 or 5 hours pre-incubation in PBS with a corresponding $\mathrm{pH}$. Data were obtained 24 hours post-incubation with PC3 cells.

static and dynamic light scattering methods. Initial biological studies were performed and it was demonstrated that this principle is applicable for real adenoviral vectors. Adenovirus type 5 was successfully coated with various concentrations of PHPMA with or without QA groups.

We demonstrated that after $2 \mathrm{~h}$ of incubating the coated virus $(10 \mathrm{mg} / \mathrm{ml}$ Cop 3$)$ with PC3 cells, the transfection ability of $\mathrm{Ad} 5$ at $\mathrm{pH} 7.4$ was decreased 2.5 times compared to transfection at $\mathrm{pH}$ 5.0. In addition, the time dependence of the incubation of coated virus particles at different $\mathrm{pH}$ levels was proved. It was shown that the transfection ability of a coated virus at $\mathrm{pH} 7.4$ is 75 times lower then transfection at $\mathrm{pH} 5.4$ with $2 \mathrm{~h}$ of pre-incubation at the corresponding $\mathrm{pH}$. This can be considered evidence of $\mathrm{pH}$ responsible shielding.

\section{Conflict of Interest}

There is no conflict of interest.

\section{Acknowledgements}

This work was supported by the Ministry of Education, Youth and Sports of the Czech Republic (grant No. EE2.3.30.0029) and by BIOCEV (CZ.1.05/1.1.00/ 02.0109) - Biotechnology and Biomedicine Centre of the Academy of Sciences and Charles University from the European Regional Development Fund and the Grant Agency of the Czech Republic (no. P301/12/1254).

\section{References}

BERGELSON JM, CUNNINGHAM JA, DROGUETT G, KURTJONES EA, KRITHIVAS A, HONG JS, HORWITZ MS, CROWELL RL, FINBERG RW: Isolation of a common receptor for coxsackie B viruses and adenoviruses 2 and 5. Science 275: 1320-1323, 1997.

CARLISLE RC, ETRYCH T, BRIGGS SS, PREECE JA, ULBRICH K, SEYMOUR LW: Polymer-coated polyethyleneimine/DNA complexes designed for triggered activation by intracellular reduction. J Gene Med 6: 337-344, 2004.

CARLISLE RC, BENJAMIN R, BRIGGS SS, SUMMER-JONES S, GILL D, HYDE S, NATHWANI A, FISHER KD, ŠUBR V, ULBRICH K, SEYMOUR LW: Coating of adeno-associated virus with reactive polymers can ablate virus tropism, enable retargeting and provide resistance to neutralising antisera. J Gene Med 10: 400-411, 2008.

CARLISLE RC, DI Y, CERNY AM, SONNEN AF, SIM RB, GREEN NK, ŠUBR V, ULBRICH K, GILBERT R, FISHER KD, FINBERG RW, SEYMOUR LW: Human erythrocytes bind and inactivate type 5 adenovirus by presenting coxsackievirus-adenovirus receptor and complement receptor 1. Blood 113: 1909-1918, 2009. 
CICHON G, BOECKH-HERWIG S, SCHMIDT HH, WEHNES E, MULLER T, PRING-AKERBLOM P, BURGER R: Complement activation by recombinant adenoviruses. Gene Ther 8: 1794-1800, 2001.

DASH PR, READ ML, FISHER KD, WOLFERT MA, OUPICKÝ D, ŠUBR V, STROHALM J, ULBRICH K, SEYMOUR LW: Decreased binding to proteins and cells of polymeric gene delivery vectors surface modified with a multivalent hydrophilic polymer and retargeting through attachment of transferrin. $J$ Biol Chem 275: 3793-3802, 2000.

ETO Y, YOSHIOKA Y, MUKAI Y, OKADA N, NAKAGAWA S: Development of PEGylated adenovirus vector with targeting ligand. Int $J$ Pharm 354: 3-8, 2008.

ETRYCH T, MRKVAN T, CHYTIL P, KOŇÁK Č, ŘÍHOVÁ B, ULBRICH K: N-(2-hydroxypropyl)methacrylamidebased polymer conjugates with $\mathrm{pH}$-controlled activation of doxorubicin. I. New synthesis, physicochemical characterization and preliminary biological evaluation. J Appl Polym Sci 109: 3050-3061, 2008.

FISHER KD, STALLWOOD Y, GREEN NK, ULBRICH K, MAUTNER V, SEYMOUR LW: Polymer-coated adenovirus permits efficient retargeting and evades neutralising antibodies. Gene Ther 8: 341-348, 2001.

FISHER KD, GREEN NK, HALE A, ŠUBR V, ULBRICH K, SEYMOUR LW: Passive tumour targeting of polymercoated adenovirus for cancer gene therapy. J Drug Target 15: 546-551, 2007.

FISHER KD, SEYMOUR LW: HPMA copolymers for masking and retargeting of therapeutic viruses. Adv Drug Delivery Rev 62: 240-245, 2010.

GREBER UF, WILLETTS M, WEBSTER P, HELENIUS A: Stepwise dismantling of adenovirus-2 during entry into cells. Cell 75: 477-486, 1993.

KNORR V, ALLMENDINGER L, WALKER GF, PAINTNER FF, WAGNER E: An acetal-based PEGylation reagent for pH-Sensitive shielding of DNA polyplexes. Bioconjugate Chem 18: 1218-1225, 2007.

KNORR V, OGRIS M, WAGNER E: An acid sensitive ketal-based polyethylene glycol-oligoethylenimine copolymer mediates improved transfection efficiency at reduced toxicity. Pharm Res 25: 2937-2945, 2008a.

KNORR V, RUSS V, ALLMENDINGER L, OGRIS M, WAGNER E: Acetal linked oligoethylenimines for use as pH-sensitive gene carriers. Bioconjugate Chem 19: 1625-1634, $2008 \mathrm{~b}$.

KOŇÁK Č, ŠUBR V, KOSTKA L, ŠTĚPÁNEK P, ULBRICH K, SCHLAAD H: Coating of vesicles with hydrophilic reactive polymers. Langmuir 24: 7092-7098, 2008.

KOSTKA L, KOŇÁK Č, ŠUBR V, ŠPÍRKOVÁ M, LAMMERS T, ADDADI Y, NEEMAN M, ULBRICH K: Removable nanocoatings of siRNA polyplexes. Bioconjugate Chem 22: 169-179, 2011.

KREPPEL F, KOCHANEK S: Modification of adenovirus gene transfer vectors with synthetic polymers: A scientific review and technical guide. Mol Ther 16: 16-29, 2008.

LAGA R, KOŇÁK Č, ŠUBR V, ULBRICH K: Coating of nanoparticles bearing amino groups on the surface with hydrophilic HPMA-based polymers. Colloid Polym Sci 285: 1509-1514, 2007.

LAGA R, KOŇÁK Č, ŠUBR V, ULBRICH K: New, hydrophilic, HPMA-based polymers for bioreversible shielding of gene delivery vectors. Macromol Chem Phys 210: 1138-1148, 2009.

LAGA R, KOŇÁK Č, ŠUBR V, ULBRICH K, SUTHIWANGCHAROEN N, NIU Z, WANG Q: Chemical conjugation of cowpea mosaic viruses with reactive HPMA-based polymers. J Biomater Sci Polym Ed 21: 1669-1685, 2010.

LECHARDEUR D, VERKMAN AS, LUKACS GL: Intracellular routing of plasmid DNA during non-viral gene transfer. Adv Drug Delivery Rev 57: 755-767, 2005.

MEYER M, WAGNER E: Recent developments in the application of plasmid DNA-based vectors and small interfering RNA therapeutics for cancer. Hum Gene Ther 17: 1062-1076, 2006.

MURUVE DA, COTTER MJ, ZAISS AK, WHITE LR, CHAN T, CLARK SA, ROSS J, MEULENBROEK RA, MAELANDSMO GM, PARKS RJ: Helper-dependent adenovirus vectors elicit intact innate but attenuated adaptive host immune responses in vivo. Mol Ther 9: S388, 2004.

NEWMAN CM, CROSDALE DJ, FISHER KD, BRIGGS SS, NORMAN KE, SEYMOUR LW, HELLEWELL PG: P-selectin dependent targeting to inflamed endothelium of recombinant P-selectin glycoprotein ligand-1 immunoglobulin chimera-coated poly[N-(2-hydroxypropyl) methacrylamide]-DNA polyplexes in vivo visualised by intravital microscopy. J Gene Med 11: 326-334, 2009. 
NIE Y, GUNTHER M, GU ZW, WAGNER E: Pyridylhydrazone-based PEGylation for pH-reversible lipopolyplex shielding. Biomaterials 32: 858-869, 2011.

O'RIORDAN CR, LACHAPELLE A, DELGADO C, PARKES V, WADSWORTH SC, SMITH AE, FRANCIS GE: PEGylation of adenovirus with retention of infectivity and protection from neutralizing antibody in vitro and in vivo. Hum Gene Ther 10: 1349-1358, 1999.

OUPICKÝ D, DIWADKAR V: Stimuli-responsive gene delivery vectors. Curr Opin Mol Ther 5: 345-350, 2003.

OUPICKÝ D, HOWARD KA, KOŇÁK Č, DASH PR, ULBRICH K, SEYMOUR LW: Steric stabilization of poly-Llysine/DNA complexes by the covalent attachement of semitelechelic poly[ $N$-(2-hydroxypropyl) methacrylamide]. Bioconjugate Chem 11: 492-511, 2000.

OUPICKÝ D, OGRIS M, HOWARD KA, DASH PR, ULBRICH K, SEYMOUR LW: Importance of lateral and steric stabilization of polyelectrolyte gene delivery vectors for extended systemic circulation. Mol Ther 5: 463-472, 2002a.

OUPICKÝ D, PARKER AL, SEYMOUR LW: Laterally stabilized complexes of DNA with linear reducible polycations: Strategy for triggered intracellular activation of DNA delivery vectors. $J$ Am Chem Soc 124: 8-9, $2002 b$.

PAPANICOLAOU I, BRIGGS S, ALPAR HO: Increased resistance of DNA lipoplexes to protein binding in vitro by surface-modification with a multivalent hydrophilic polymer. J Drug Targeting 12: 541-547, 2004.

PRILL J-M, ŠUBR V, PASQUARELLI N, ENGLER T, KOCHANEK S, ULBRICH K, KREPPEL F: Traceless bioresponsive shielding of Adenovirus hexon with HPMA copolymers maintains transduction capacity in vitro and in vivo. Plos One 9: e82716, 2014.

ROBERTS DM, NANDA A, HAVENGA MJE, ABBINK P, LYNCH DM, EWALD BA, LIU J, THORNER AR, SWANSON PE, GORGONE DA, LIFTON MA, LEMCKERT AAC, HOLTERMAN L, CHEN B, DILRAJ A, CARVILLE A, MANSFIELD KG, GOUDSMIT J, BAROUCH DH: Hexon-chimaeric adenovirus serotype 5 vectors circumvent pre-existing anti-vector immunity. Nature 441: 239-243, 2006.

ROLLAND A, FELGNER PL: Non-viral gene delivery systems - Preface. Adv Drug Delivery Rev 30: 1-3, 1998.

SAITO G, SWANSON JA, LEE KD: Drug delivery strategy utilizing conjugation via reversible disulfide linkages: role and site of cellular reducing activities. Adv Drug Delivery Rev 55: 199-215, 2003.

SIMS K, AHMED Z, READ ML, COOPER-CHARLES L, GONZALEZ AM, FISHER KD, BERRY M, SEYMOUR LW, LOGAN A: In vitro evaluation of a 'stealth' adenoviral vector for targeted gene delivery to adult mammalian neurones. J Gene Med 11: 335-344, 2009.

ŠUBR V, ULBRICH K: Synthesis and properties of new $N$-(2-hydroxypropyl)methacrylamide copolymers containing thiazolidine-2-thione reactive groups. React Funct Polym 66: 1525-1538, 2006.

ŠUBR V, KOŇÁK Č, LAGA R, ULBRICH K: Coating of DNA/poly(L-lysine) complexes by covalent attachment of poly[N-(2-hydroxypropyl)methacrylamide]. Biomacromolecules 7: 122-130, 2006.

ŠUBR V, KOSTKA L, SELBY-MILIC T, ULBRICH K, SEYMOUR LW, CARLISLE RC: Coating of adenovirus type 5 with polymers containing quaternary amines prevents binding to blood components. $J$ Control Release 135: 152-158, 2009.

SUMIDA SM, TRUITT DM, LEMCKERT AAC, VOGELS R, CUSTERS JHHV, ADDO MM, LOCKMAN S, PETER T, PEYERL FW, KISHKO MG, JACKSON SS, GORGONE DA, LIFTON MA, ESSEX M, WALKER BD, GOUDSMIT J, HAVENGA MJE, BAROUCH DH: Neutralizing antibodies to adenovirus serotype 5 vaccine vectors are directed primarily against the adenovirus hexon protein. $J$ Immunol 174: 7179$7185,2005$.

TANNOCK IF, ROTIN D: Acid pH in tumors and its potential for therapeutic exploitation. Cancer Res 49: 4373-4384, 1989.

ULBRICH K, ŠUBR V, STROHALM J, PLOCOVÁ D, JELÍNKOVÁ M, ŘíHOVÁ B: Polymeric drugs based on conjugates of synthetic and natural macromolecules I. Synthesis and physico-chemical characterisation. J Control Release 64: 63-79, 2000.

WALKER GF, FELLA C, PELISEK J, FAHRMEIR J, BOECKLE S, OGRIS M, WAGNER E: Toward synthetic viruses: Endosomal $\mathrm{pH}$-triggered deshielding of targeted polyplexes greatly enhances gene transfer in vitro and in vivo. Mol Ther 11: 418-425, 2005. 
WICKHAM TJ, TZENG E, SHEARS LL, ROELVINK PW, LI Y, LEE GM, BROUGH DE, LIZONOVA A, KOVESDI I: Increased in vitro and in vivo gene transfer by adenovirus vectors containing chimeric fiber proteins. J Virol 71: 8221-8229, 1997. 


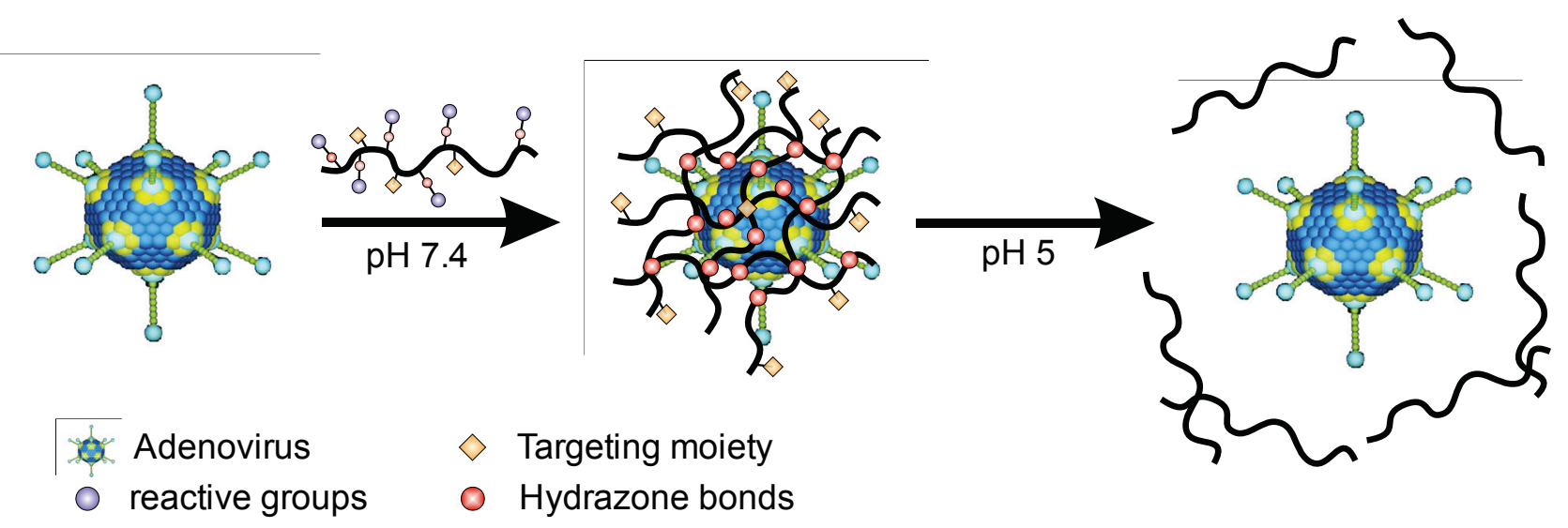

Schema 1. Principle of $\mathrm{pH}$ sensitive coating. 

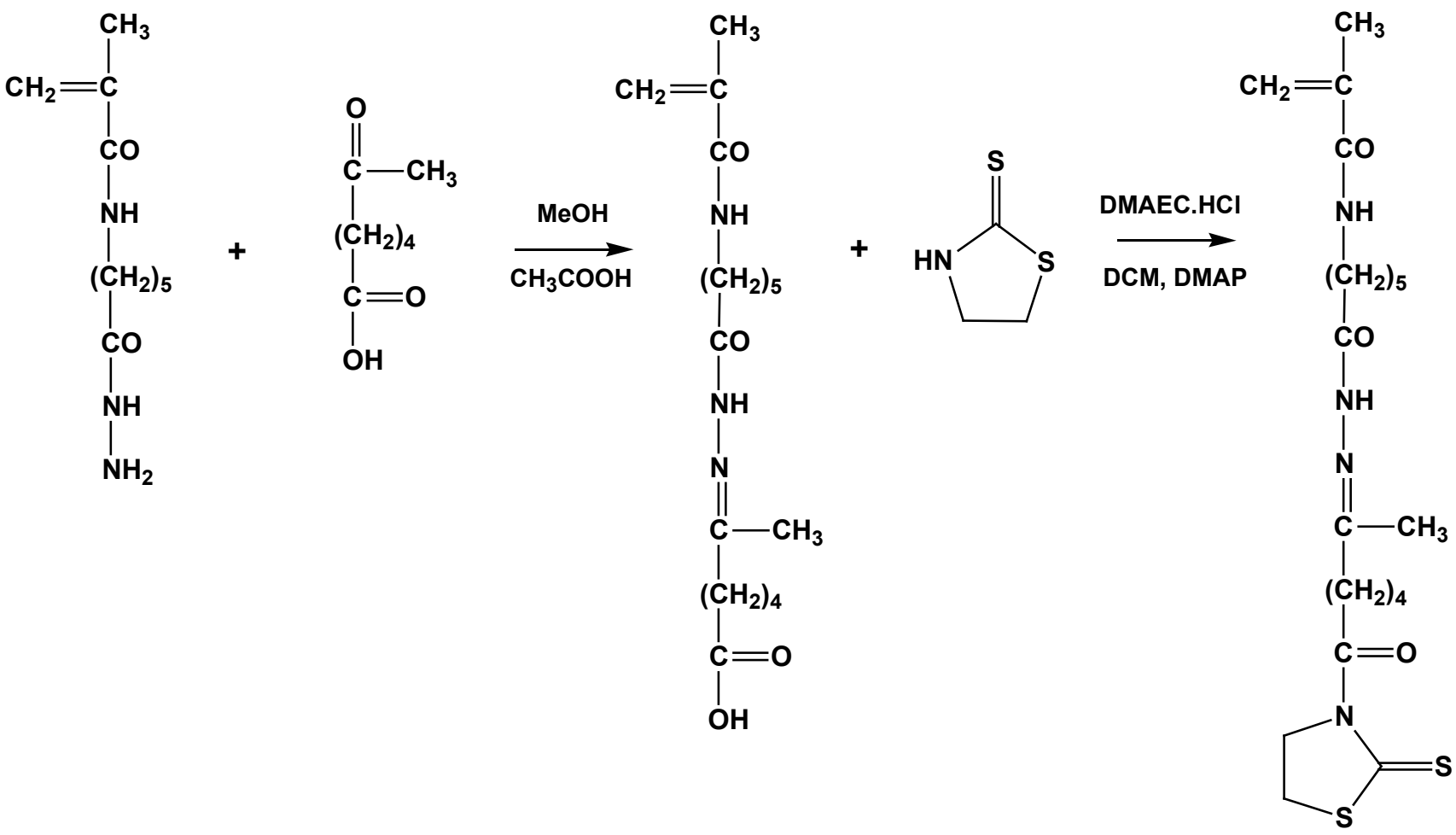

Schema 2. Synthesis of monomer. 

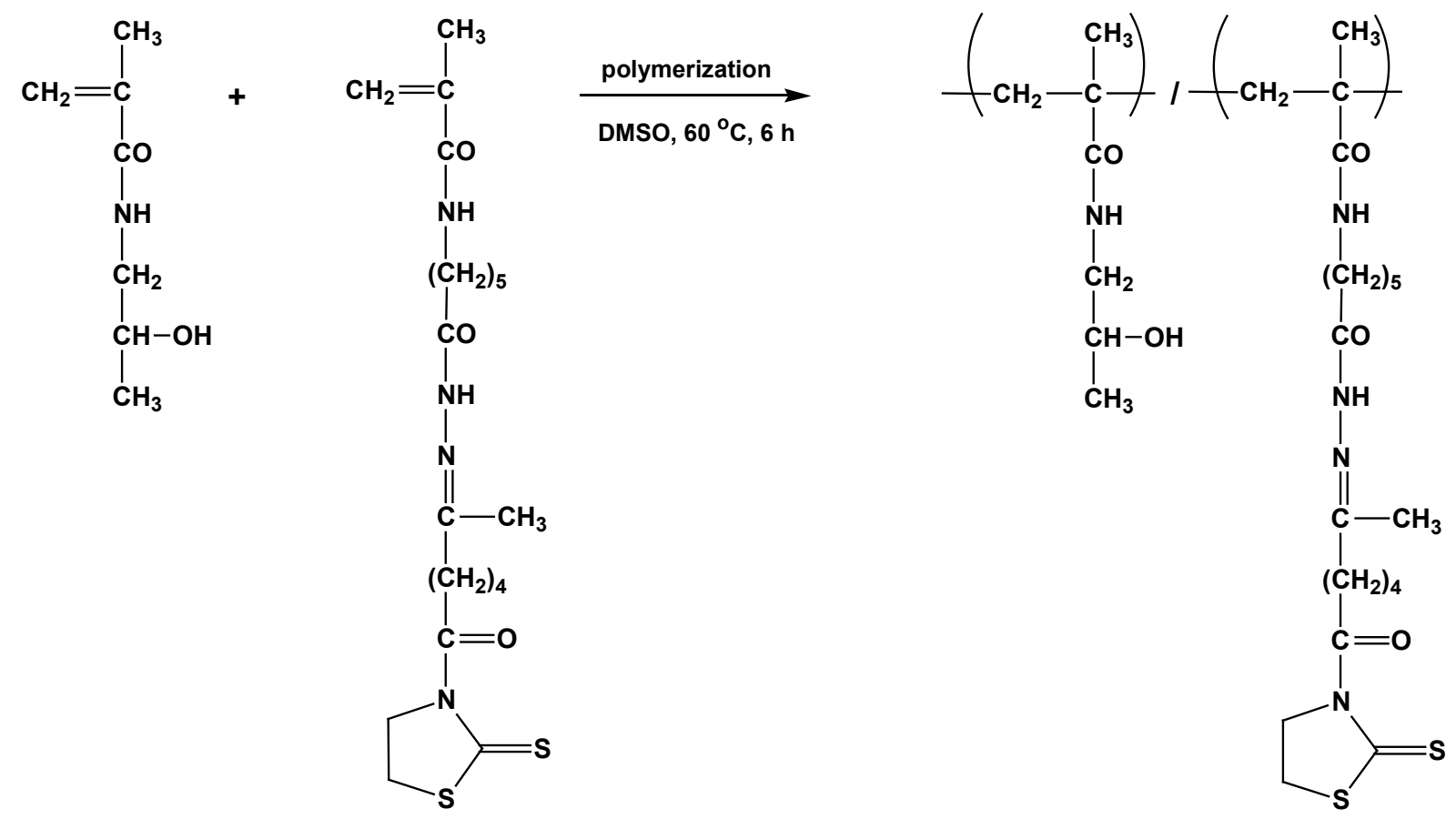

Schema 3. Synthesis of HPMA copolymer with OHA linker. 


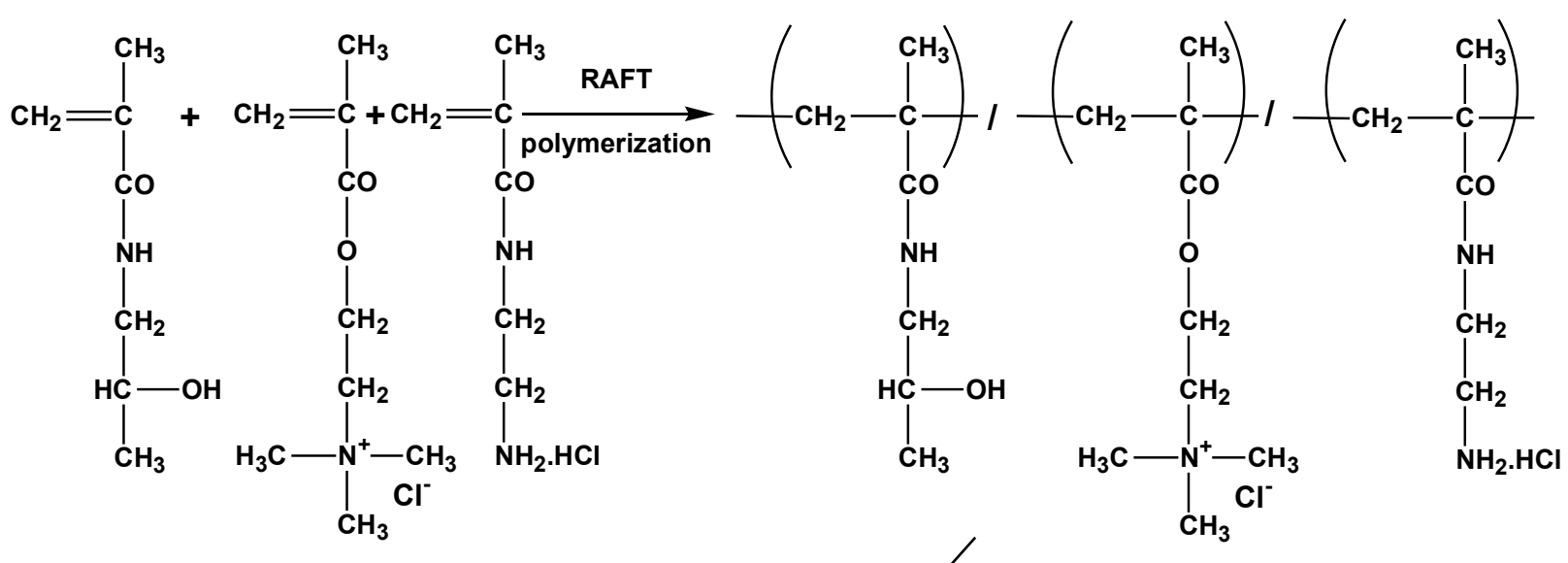

1) OPA-TT

2) HNA-TT.TFA, $\mathrm{Et}_{3} \mathrm{~N}$

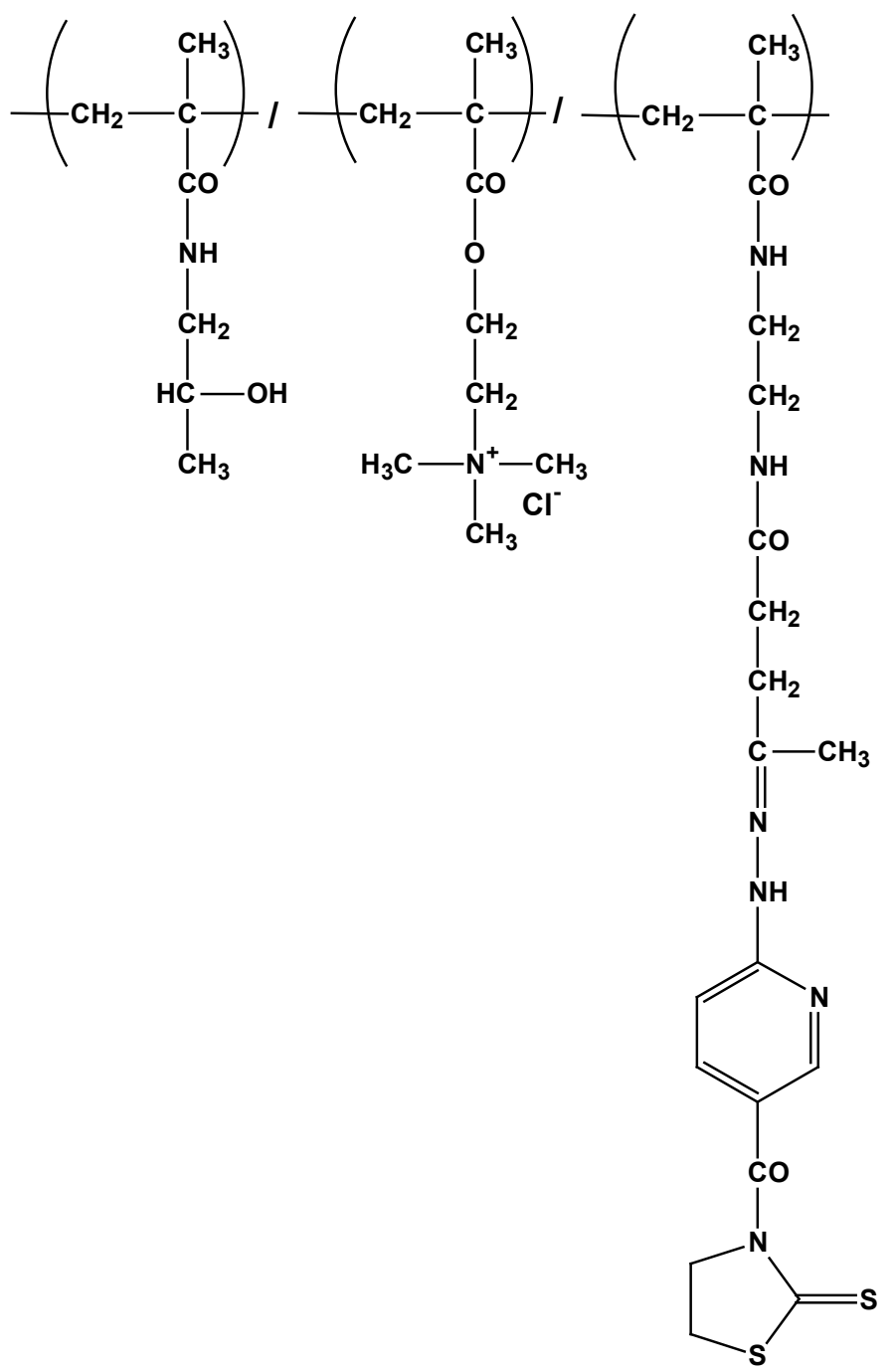

Schema 4. Synthesis of HPMA copolymer with NHA linker and QA groups. 